\title{
Prediction of adverse pregnancy outcome in patients with antiphospholipid antibodies
}

\author{
Sarita Chaudhary ${ }^{1}$, Charusmita Agrawal $^{2}$, Deepak Kumar ${ }^{3}$
}

\author{
${ }^{1}$ Department of Gynecology, Civil Hospital, Gurgaon, Uttar Pradesh, India \\ ${ }^{2}$ Department of Obstretics and Gynecology, SMS Hospital, Jaipur, Rajasthan, India \\ ${ }^{3}$ Consultant, Urosurgeon, Medanta Hospital, Gurgaon, Uttar Pradesh, India
}

Received: 16 March 2016

Received: 04 April 2016

Accepted: 16 April 2016

\author{
*Correspondence: \\ Dr. Sarita Chaudhary, \\ E-mail: scientificwritingsolutions@gmail.com
}

Copyright: (c) the author(s), publisher and licensee Medip Academy. This is an open-access article distributed under the terms of the Creative Commons Attribution Non-Commercial License, which permits unrestricted non-commercial use, distribution, and reproduction in any medium, provided the original work is properly cited.

\begin{abstract}
Background: Immunological cause play an important role in abnormal pregnancy outcome, in which antiphospholipid syndrome is one of the growing cause of concern. The objective of the study was to investigate serologic prediction of adverse pregnancy outcome in patients with antiphospholipid antibody (APL) and to test the hypothesis that a serologic variable can identify women at highest risk of adverse pregnancy outcome.

Methods: A cross sectional, observational study including total 250 pregnant women, divided in five groups including patients with recurrent abortion, patients with IUGR, patients with pre eclampsia, patients with preterm labour having 50 patients each and control group of 50 pregnant females without any complications. Comparison of each group for the presence of anti phospholipid antibodies (both $\operatorname{IgG}$ and $\mathrm{IgM}$ ) with control group was performed. Data collected were analyzed using appropriate statistical tests.

Results: Antiphospholipid antibodies in patients of obstetric and fetal complications were abnormally high. IgG antibody was found in pre-eclampsia (62\%), prematurity (54\%), recurrent fetal loss $(44 \%)$ and intrauterine growth retardation (54\%), IgM antibody was also found in pre-eclampsia (54\%), prematurity (32\%), recurrent fetal loss $(30 \%)$ and intrauterine growth retardation $(40 \%)$. Presence of $\mathrm{IgG}$ antiphospholipid antibody in comparison with controls is statistically significant in patient of preeclampsia and recurrent fetal loss.

Conclusions: Early autoimmune screening for antiphospholipid antibodies (IgM, IgG) of pregnant ladies was found to be effective tool in predilection of obstetric and fetal complications.
\end{abstract}

Keywords: Pre-eclampsia, Prematurity, Recurrent fetal loss, Intrauterine growth retardation, Antiphospholipid antibody

\section{INTRODUCTION}

Immunological cause play an important role in abnormal pregnancy outcome, in which antiphospholipid syndrome is one of the growing cause of concern.

Antiphospholipid syndrome (APS) was first defined as a syndrome in 1983. Consisting of a triad of manifestations involving arterial and/or venous thrombosis, recurrent fetal loss, accompanied by mild to moderate thrombocytopenia and elevated titers of antiphospholipid (APL) antibodies: lupus anticoagulant (LA) and/or anticardiolipin antibodies (aCL). Today, this syndrome is known to be systemic and may affect almost every organ and tissue in the body. The cause of APS is still considered a mystery - yet, as in many other autoimmune diseases, a combination of environmental and genetic factors has been proposed. Recent data indicate that infectious agents may play a major role in the etiology of APS. The pathophysiology of APS includes all arms of the coagulation system. ${ }^{1}$

Systemic thromboembolism is the principal manifestation of APS. Thrombi in the placental circulation and the 
beneficial effect of antithrombotic therapy in APS patients suffering from recurrent pregnancy loss (RPL) suggest a central role for this mechanism in reproductive failure. $^{2}$

Antiphospholipid antibodies (aPL) are a heterogeneous group of autoantibodies directed against different antigens, predominantly anionic phospholipids or phospholipid-containing structures. aPL have been associated with pregnancy disorders, including spontaneous miscarriage, recurrent miscarriage, pregnancy-induced hypertension, preeclampsia, and intrauterine growth retardation. ${ }^{3}$

\section{METHODS}

A comparative, cross sectional, observational study was conducted on 250 pregnant patients presenting to the Department of Obstetrics and Gynecology at tertiary care teaching hospital of Rajasthan, India.

They were divided into two groups:

Study group was further divided into 4 groups with 50 pregnant women in each group; (a) history of recurrent abortion; (b) history of IUGR; (c) history of preeclampsia (d) history of preterm labour.

Control group included healthy 50 pregnant woman without any history of miscarriages/ IUGR/ Preeclampsia/pre-term labour.

Method of collection of data was approved from institutional ethics committee was taken before starting the study. The study was explained to them in brief in a language they can understand. Consent of participants was taken in written informed consent form.

\section{Inclusion criteria}

- $\quad$ Age - 18 to 41 years of age

- $\quad$ LMP - 12-24 weeks of pregnancy

\section{Exclusion criteria}

- Patients of age less than eighteen years.

- Absence of any systemic disease.

The blood sample was collected from these patients and serum sample evaluated for $\operatorname{IgG}$ and $\operatorname{IgM}$ antibodies against antiphopholipid utilizing ELISA. All data collected were analyzed using appropriate statistical tests.

\section{RESULTS}

In our study we found that the maximum percentage of IgG \& IgM positivity was in age group of 25-30 year in both case and control group. As gravidity increases, positivity of antiphospholipid increases with in control and cases.

- In group of repeated abortions prevalence of $\operatorname{IgG}, \operatorname{IgM}$ was $44 \%$ and $30 \%$ respectively in case group while in control group \& prevalence of IgG, IgM $19 \%$ and $10 \%$ respectively.

Table 1: Comparative analysis between APA levels in healthy pregnant females and females with recurrent fetal loss.

\begin{tabular}{|lll|l|}
\hline APA levels & $\begin{array}{l}\text { Control } \\
(\mathbf{N}=50)\end{array}$ & $\begin{array}{l}\text { Case } \\
(\mathrm{N}=50)\end{array}$ & P value \\
\hline IgG & & & \\
\hline Positive & 9 & 22 & 0.009 \\
\hline Negative & 41 & 28 & \\
\hline IgM & & & 0.024 \\
\hline Positive & 5 & 15 & \\
\hline Negative & 45 & 35 & \\
\hline
\end{tabular}

Table 2: Comparative analysis between APA levels in healthy pregnant females and females with IUGR.

\begin{tabular}{|lcc|c|}
\hline APA levels & $\begin{array}{c}\text { Control } \\
(\mathbf{N}=50)\end{array}$ & $\begin{array}{l}\text { Case } \\
(\mathbf{N}=50)\end{array}$ & P value \\
\hline IgG & & & \\
\hline Positive & 17 & 27 & 0.07 \\
\hline Negative & 33 & 23 & \\
\cline { 1 - 2 } & & & \multirow{2}{*}{0.014} \\
\hline Positive & 8 & 20 & \\
\hline Negative & 42 & 30 & \\
\hline
\end{tabular}

Table 3: Comparative analysis between APA levels in healthy pregnant females and females with pre eclampsia.

\begin{tabular}{|lll|l|}
\hline APA levels & $\begin{array}{l}\text { Control } \\
(\mathbf{N}=50)\end{array}$ & $\begin{array}{l}\text { Case } \\
(\mathbf{N}=50)\end{array}$ & P value \\
\hline IgG & & & \\
\hline Positive & 15 & 31 & 0.003 \\
\hline Negative & 35 & 19 & \\
\hline IgM & & & \multirow{2}{*}{0.61} \\
\hline Positive & 13 & 23 & \\
\hline Negative & 37 & 27 & \\
\hline
\end{tabular}

Positivity of IgG antiphospholipid antibody is higher in patient with IUGR compare to control group. Strongly positive IgM APA patients were $40 \%$, while in control it was only $16 \%$. Prevalence of $\operatorname{IgG}$ antibody in patients with IUGR was $54 \%$, which is much higher than control group (34\%).

In preeclamptic patients prevalence of $\operatorname{IgG}$ and $\operatorname{IgM}$ was $62 \%$ and $46 \%$, which was higher than prevalence of $\mathrm{IgG}$ $(30 \%)$ and $\operatorname{IgM}(23 \%)$ in control group. 
Table 4: Comparative analysis between levels of APA levels in healthy pregnant females and females with pre-term labour.

\begin{tabular}{|lccl|}
\hline APA levels & $\begin{array}{c}\text { Control } \\
(\mathrm{N}=50)\end{array}$ & $\begin{array}{l}\text { Case } \\
(\mathrm{N}=50)\end{array}$ & P value \\
\hline IgG & & & \multirow{2}{*}{0.015} \\
\hline Positive & 14 & 27 & \\
\hline Negative & 36 & 23 & 0.04 \\
\hline IgM & & & \\
\hline Positive & 06 & 16 & \\
\hline Negative & 44 & 34 & \\
\hline
\end{tabular}

\section{DISCUSSION}

Age

In accordance in our study Parazzini et al 1991 reported that the maximum number of patients with IgG APA positive were $38 \%$ in age group of 25-29 years. ${ }^{4}$

Kalra S, Tuli A, Goyal U et al reported that maximum number of IgG APA positive patients of 26-30 years age group is $24 \% .^{5}$

\section{Recurrent fetal loss}

It is a known fact that presence of IgG APA is very important risk factor in $\mathrm{I}^{\text {st }}$ trimester abortion. In our study prevalence rate in case group was $44 \%$. Our observation is in close conformity with a study by Maier DB. Parke A in which prevalence of IgG acl was $30 \%$ in the patient with history of recurrent abortion and was found positive in $8 \%$ of controls. ${ }^{6}$ Creagh MD, Malia RG, Cooper SM et al studied 35 patient with recurrent pregnancy loss out of which 7 were positive for IgG APA.

As in above all studies the prevalence of $\operatorname{IgG}$ APA is between $11-52.4 \%$ in patients of recurrent abortion which is in concordance to our study, where prevalence was around $44 \%$.

In a study by Lockwood et al on 55 patients, it was observed that $18 \%$ of recurrent abortions had raised level of IgM APA. ${ }^{8}$ Cowchowk et al observed in $75 \%$ patients with recurrent abortions had raised levels of IgM APA. ${ }^{9}$ Silver et al found the prevalence of IgM ACL $20.4 \%$ in their study. ${ }^{10}$

\section{Pregnancy induced hypertension}

Lockshin et al, Branch et al, Kwak et al, and Balasch et al showed that positive results for antiphospholipid antibodies are associated with adverse pregnancy outcome especially IUGR as well as with maternal complications including thrombosis, thrombocytopenia and pregnancy induced hypertension (PIH). ${ }^{11,12}$ Backos M, Rai R, Baxter N, Chitcott IT, Cohen H, Regan L et al studied $17 \%$ of patients with gestational hypertension were APA positive. ${ }^{13}$

\section{IUGR}

Lima F, Khamshta MA, Buechnan NM, Kerslake S, Hunt BJ, Hughej GR et al showed prevalence of IUGR in their study was $31 \%$ in IgG APA positive patients. ${ }^{14}$

Clark et al observed that aPL seems to be detectable in $25 \%$ of women delivering growth restricted fetuses. ${ }^{15}$

\section{Pre maturity}

Lima F, Khamshtha, MA, Buchanan NM, Kerslake S, Hunt BJ showed prevalence of prematurity was $43 \%$ in all patients with APA positive. ${ }^{14}$

Nossent HC, Swak TJ et al showed the prevalence of prematurity $6-35 \%$ of lupus pregnancies.

\section{CONCLUSION}

Early autoimmune screening for antiphospholipid antibodies (IgM, IgG) of pregnant ladies was found to be effective tool in predilection of obstetric and fetal complications

Funding: No funding sources Conflict of interest: None declared

Ethical approval: The study was approved by the Institutional Ethics Committee

\section{REFERENCES}

1. Bates SM, Greer IA, Pabinger I, Sofaer S, Hirsh J, American College of Chest Physicians. Venous thromboembolism, thrombophilia, antithrombotic therapy, and pregnancy: American College of Chest Physicians Evidence-Based Clinical Practice Guidelines (8th edn). Chest. 2008;133(6Suppl):844S-86S.

2. Balasch J1, Creus M, Fábregues F, Reverter JC, Carmona F, Tàssies D et al. Antiphospholipid antibodies and human reproductive failure Hum Reprod. 1996;11(10):2310-5.

3. Branch DW, Silver RM, Blackwell JL, Reading JC, Scott JR. Outcome of treated pregnancies in women with antiphospholipid syndrome: an update of the Utah experience. Obstet Gynecol. 1992;80:614-20.

4. Parazzini F, Acaia B, Faden D. Antiphospholipid antibodies and recurrent miscarriage. Obstet Gynecol. 1991;77:854-8.

5. Kalra S, Tuli A, Goyal U, Choudhary R, Raheja S. Correlation of Anticardiolipin Antibody IgM With First Trimester Recurrent Abortions. Journal of the Anatomical Society of India. 2002;51(1):1-6.

6. Maier DB, Parke A. Subclinical autoimmunity in recurrent aborters. Fertil Steril. 1989 ;51(2):280-5. 
7. Creagh MD, Malia RG, Cooper SM, Smith AR, Duncan SL. Screening for lupus anticoagulant and anticardiolipin antibodies in women with fetal loss. J Clin Pathol. 1991;44(1):45-7.

8. Lockwood CJ, Romero R, Feinberg RF. The prevalence and biologic significance of lupus anticoagulant and anticardiolipin antibodies in general obstetric population. American Journal of Obstetrics \& Gynecology. 1989;16:369-73.

9. Cowchock S, Smith JB, Gocial B. (1986): Antibodies to phospholipids and nuclear antigens in patients with repeated abortions. American Journal of obstetrics \& gynecology. 1986;155:1002-10.

10. Silver RK, MacGregor SN, Sholl JS, Hobart JM, Neerhof MG, Ragin A. (1993). Comparative trial of prednisone plus aspirin versus aspirin alone in the treatment of anticardiolipin antibody-positive obstetric patients. Am J Obstet Gynecol. 1993;169(6):1411-7.
11. Lockshin MD. Antiphospholipid antibody. J Am Med Assoc. 1997;277:1549-51.

12. Branch DW, Silver RM, Blackwell JL, Reading JC, Scott JR. Outcome of treated pregnancies in women with antiphospholipid syndrome: an update of the Utah experience. Obstet Gynecol. 1992;80:614-20.

13. Backos M, Rai R, Baxter N, Chilcott IT, Cohen H, Regan L. Pregnancy complications in women with recurrent miscarriage. 1999;106(2):102-7.

14. Lima F, Khamashta MA, Buchanan NM, Kerslake S, Hunt BJ, Hughes GR. A study of sixty pregnancies in patients with the antiphospholipid syndrome. Clin Exp Rheumatol. 1996;14(2):131-6.

15. Clark EA, Silver RM, Branch DW. (2007). Do antiphospholipid antibodies cause preeclampsia and HELLP syndrome? Curr Rheumatol Rep. 2007;9(3):219-25.

Cite this article as: Chaudhary S, Agrawal C, Kumar D. Prediction of adverse pregnancy outcome in patients with antiphospholipid antibodies. Int J Reprod Contracept Obstet Gynecol 2016;5:1613-6. 